\title{
Progressive Muscle Relaxation of Compelemtary Therapy and Sirma's Dyeing tea for Decreasing Blood Pressure on the Hypertension
}

\author{
Wahyuni ${ }^{1}$, Ika Silvitasari ${ }^{2}$ \\ ${ }^{l}$ (Lecturer of Nursing at STIKES 'Aisyiyah Surakarta-Indonesia) \\ ${ }^{2}$ (Lecturer of Nursing at STIKES 'Aisyiyah Surakarta-Indonesia)
}

\begin{abstract}
:
Study Objective: Hypertension is a disease which gets the attenions of people because the number of victims increase continually. It needs the a good treatment beacuse of hypertension can be a risk of other diseases such as heart attack, kidney, nerve, and vascular diseases. This research aims to analyze the influences of progressive muscle relaxation of complementary therapy and SIRMA'S (mangosteen skin and the leaf of soursop) dyeing tea as the treatment for decreasing the blood pressure on hypertension's victims.

Method and Measurement: This research is a design with pre post test one group of experimental quasi. The place of research is in Posyandu Eldery, Sidorejo, Sukoharjo. Collecting sample is conducted by purposive sample for Eldery in Posyandu, Sidorejo that is about 20 respondents, data analysis uses Paired T-test.

Result: There is significantly influences in giving Progressive Muscle Relaxation and SIRMA Dyeing Tea therapy toward the hypertension level on Eldery with $p=0,000$.

Conclusion: Progressive Muscle Relaxation and SIRMA Dyeing Tea therapy has the significant influence toward the hypertension level on eldery, so this therapy can be recommended as one of the hypertension complementary therapies.
\end{abstract}

Keywords: hypertension, Progessive Muscle Relaxation, SIRMA (Sirsat Manggis).

\section{Introduction}

Hypertension is a health disturbance that often seen with a high prevelance rate so the evaluation of using drugs needs to be done. Hypertension has killed about 9,4 million people in the world every year. Nowadays, the percentage of hypertension victims mostly occurs in the growing countries. There are $40 \%$ of growing countries have the hypertension victims, then the developing countries are just $35 \% .^{1}$ In Asia, this disease has killed 1,5 million people every year. Men have stepped up of the amount of victims from $18 \%$ to 31 $\%$ and women have increased from $16 \%$ to $29 \%$. ${ }^{1}$ The prevalency of hypertension in Indonesia on people who has > 18 years old are $29,8 \%$. It can be found at 10 provinces of Indonesia from the highest to lower, such as Riau, Bangka Belitung, Central Java, DI Yogyakarta, East Java, NTB, Central of Kalimantan, South of Kalimantan, Central of Sulawesi, and West of Sulawesi. ${ }^{2}$

The cause factors of hypertension include age, stress, obesity, smoking, alcohol, kidney abnormalities, and others. The effects of hyperpressure can make the damage of organs such as the kidney, heart, liver, eyes until the disfunction of motion organs. ${ }^{3}$ Hypertension can be controlled by giving the hypertension healing, it is divided into two ways such as pharmachology healing and non pharmachology healing. The pharmachology healing aims to decrease the blood pressure by using anti-hypertension drugs, then the complementary healing non pharmachology hypertension is a pharmachology drug which completed by the non pharmachology healing such as relaxation, herbal, physical treatment, etc. Based on the background above, it formulates that " Are there the influences of giving SIRMA tea and Progressive Muscle Relaxation for decreasing the blood pressure on hypertension victims in Posyandu of Eldery people, Sidorejo, Bendosari, Sukoharjo?", then the purpose of this research is to analyze the influences of Progessive Muscle Relaxation of complementary therapy and SIRMA tea as an effort for decreasing the blood pressure on hypertension victims.

\section{Material And Method}

The research design is Quasi Experimen design with pre post test one group. The study conducted from 21-27 juny 2016 in Posyandu Sidorejo, Bendosari, Sukoharjo.The total of sample in this research is 20 respondents. The way of collecting sample is purposive sample. The inclusion criteria is eldery with hypertension and that joined at Posyandu, the eldery people are willing to be respondent. The exclusion criteria is the eldery people who consume the hypertension drug and they have not included the half of drug period and not willing to be respondent. Variable research is : 
a. Progressive Muscle Relaxation : the muscle relaxation treatment that consists of 7 motions, done at 2 times on a day, one hour after eating during one week.

b. SIRMA tea: the SIRMA dyeing tea has served and provided by the factory, one sachet of tea contains 20 gram of mangosteen skin and the leaf of soursop, consumed for twice in a day, one hour before doing Progressive Muscle Relaxation treatment.

c. Blood pressure : checking blood pressure conducted before given the therapy and after one week after conducted therapy.

The analyzing data in this research uses paired T-test.

The respondents'distributions is:

Table 1. Distribution respondents characteristicsbased on age

\begin{tabular}{|l|l|l|l|}
\hline No & Age & Frequency & Percentage $(\%)$ \\
\hline 1. & $60-69$ & 17 & 56,67 \\
\hline 2. & $70-79$ & 10 & 33,33 \\
\hline 3. & $80-89$ & 3 & 10 \\
\hline & Total & 30 & 100 \\
\hline
\end{tabular}

The frequency distribution of respondent level before and after given the Progressive Muscle Relaxation Therapy and SIRMA tea in Posyandu III

Table. 2. Distribution on hypertension respondent level before given the Progressive Muscle Relaxation Therapy and SIRMA tea in Posyandu III

\begin{tabular}{|l|l|l|l|l|}
\hline No & Hypertension Level & Category & Frequency & Percentage (\%) \\
\hline 1. & No hypertension & $<130$ & 0 & 0 \\
& Basic & $130-139$ & 0 & 0 \\
\hline 2. & Hypertension level 1 & $140-159$ & 8 & 26,67 \\
\hline 3. & Hypertension level 2 & $160-179$ & 16 & 53,33 \\
\hline 4 & Hypertension level 3 & $\geq 180$ & 6 & 20 \\
\hline & Total & & 30 & 100 \\
\hline
\end{tabular}

Table. 3. Distribution on hypertension respondent level after given the Progressive Muscle Relaxation Therapy and SIRMA tea in Posyandu III

\begin{tabular}{|l|l|l|l|l|}
\hline No & Hypertension Level & Category & Frequency & Percentage (\%) \\
\hline 1. & No hypertension & $<130$ & 1 & 3,33 \\
& Basic & $130-139$ & 2 & 6,67 \\
\hline 2. & Hypertension level 1 & $140-159$ & 13 & 43,33 \\
\hline 3. & Hypertension level 2 & $160-179$ & 12 & 40 \\
\hline 4 & Hypertension level 3 & $\geq 180$ & 2 & 6,67 \\
\hline & Total & & 30 & 100 \\
\hline
\end{tabular}

Table. 4. Analysis different level hypertension on the eldery people before and after given progressive muscle relaxation therapy and SIRMA tea in Posyandu III.

\begin{tabular}{|l|l|l|l|l|l|l|}
\hline $\begin{array}{l}\text { The level of hypertension on } \\
\text { eldery people }\end{array}$ & $\mathrm{N}$ & Mean & Median & SD & Min-max & p-value \\
\hline Before therapy & 30 & 162,83 & 160 & 13,04 & $140-180$ & 0,000 \\
\hline After therapy & 30 & 144,83 & 140 & 11,48 & $120-165$ & \\
\hline
\end{tabular}

Result given progressive muscle relaxation therapy and SIRMA tea in Posyandu III analysis on the level hypertention before and after intervention is:

Table. 5. Analysis test result of level progressive muscle relaxation therapy and SIRMA tea on the hypertention level.

\begin{tabular}{|l|l|l|l|l|l|}
\hline Variable & N & Mean & SD & CI & p-value \\
\hline Hypertention level & 30 & 18 & 10,39 & $14,12-21,88$ & 0,000 \\
\hline
\end{tabular}

\section{Discussion}

a. Age

Age is one of risk factor which happened hypertension. By increasing the age so the risk of getting hypertension will be twice. This case caused of at the time, there are many self changing of human. This change in physics, psychological condition, economics, social, and spiritual which influence the life quality of a eldery one. ${ }^{4}$ According to LeMone \& Burke said that the essential (primary) hypertension influences the middle age and mature until elder. ${ }^{5}$ The patients who are more than 60 years old, $50-60 \%$ have the higher blood pressure or $140 / 90 \mathrm{mmHg}$. This case is a influence of degeneration which happens on people who are old by the time. ${ }^{6}$ 


\section{b. The Level of Hypertension before and after given Progressive Muscle Relaxation Therapy and SIRMA Tea}

The technique of Progressive Muscle Relaxation is a technique of muscle relaxation which does not need imagination, application or suggestion. One of this technique is combining the deep breathing treatment and a set of relaxation and contraction on certain muscles. Technique of progressive muscle relaxation may allow the patients to control their body response. ${ }^{7}$ The changes happen on relaxation or after that which can influence the work of emotion otonom nerve and the effect of relaxation can be appeared by this relaxation which can change the sympatic of dominant phsychology to be a parasympatic of dominant system. In this situation, hypersecrection of catecholamine and chortisole are dropped and increasing the parasympatic hormone then neurotransmitter such as DHEA (Dehidroepinandrosteron) and dopamine or endorphin. The regulation system of Parasympatics finally can appear a relax effect. ${ }^{8}$ So that the relaxation that produced from progressive muscle relaxation can be useful for decreasing hypertension. According to Murti this relax condition can stimulate the body to produce a molecule which called nitrat oxidation (NO). This molecule works on artery tonus so it can drop the blood pressure. ${ }^{9}$

\section{c. The Influence of Giving Progressive Muscle Relaxation Theraphy and SIRMA Tea for Decreasing the Blood Pressure}

The difference of influence in giving progressive muscle relaxation therapy and SIRMA dyeing tea for decreasing the level of hypertension can be known through p-value $(0.000)$ with CI $95 \%$. In this research, it can be concluded that there are the influence of giving progressive muscle relaxation therapy and SIRMA tea with the level of hypertension on eldery people in Posyandu III Sidorejo, Health Center Area Bendosari, Sukoharjo. This research is appropriate with the result of previous research conducted by Tyani. E.S et all which found that giving progressive muscle relaxation was effective to drop the blood pressure on essential hypertension victims. ${ }^{10}$ Then, this research are also deal with Chen research which shows that hypertension victims who treatment the physical practice get a decreasing of the systolic blood pressure and decreasing the dyastolic blood pressure. ${ }^{11}$ Sulistiyarini tells that relaxation can drop the systolic blood pressure or systolic on hypertension victims. ${ }^{12}$

The result of this research also supported by the statement of Varvogli dan Darvin which say that the various of technique and relaxation can drop the blood pressure on hypertension victims. ${ }^{13}$ Shinde N. et.all. also support the result of this research is the significance of Jacobson"s progressive muscular relaxation is effective to decrease the blood pressure on hypertension victims. ${ }^{14}$ The progressive muscle relaxation is a motion of muscle realxation which can slow down tension between muscle and nerve. Hypertension can effect the tension on muscle which send stimulant to the brain and make a way to feed back. When there is a hypertension part from the way to feed back, the body will be closed between muscles and mind. The progressive muscle relaxation will obstruct its way by activating the system of parasysmatic nerve and manipulate hypotalamus through centering mind to get the positive thing so the stress stimulant is drop for hypotalamus. The progressive muscle relaxation is an intervention treatment to get the comfortness physically. Relaxation is a form of mindbody therapy in alternative and complementary therapies. ${ }^{15}$

According to Maghfirah. et. al relaxation only happens when the mind and body are relax, then when brain ritme changed form beta to alpha. ${ }^{16}$ This condition causes a dropped anxiety and blood current to muscle also drop down, contrastly the blood goes to brain and skin so it gives a harmful and relax feeling. The research done by Khumuta, Aruna, Poongodi show that the technique of progressive muscle relaxation is effective to decrease the stress and blood pressure. The work of progressive muscle relaxation is by activating the system of parasympatic nerve and stopping the work system of sympatic nerve. If the sympatic system is ostructed so this process will be down so the chortisol is also dropped. Then if a client conducts this relaxation continually so he will get more comfort in thinking and he also can manage his stress and his breathing. ${ }^{17}$

The other non pharmachology therapy which can decrease hypertension is herbal way. There are some herbal plants which can be used for decreasing blood pressure such as star fruit, mellon, celedry, and cucumber. ${ }^{18}$ SIRMA tea is a combination between soursop leaves and mangosteen skin which processed to be a dyeing tea. One of the special benefit of this tea is that it can decrease the blood pressure with consuming tea twice in a day during one week. The research conducted by Pugar gets the result of tea which processed from soursop leaves has the effect to decrease the blood pressure in normal systolic and dyastolic for men in adult. ${ }^{19}$ The other research conducted by Sriyono and Jujul, show that there are the difference between the tension of systolic and dyastlic before and after given green tea. ${ }^{20}$ Then cholesterol amount before and after given green tea shows that there is no diffrence in a meaning. Research conducted by Nwokocha et.al show that giving muricata (soursop leaves) $9.17-48,5 \mathrm{mg} / \mathrm{kg}$ significantly can decrease the blood pressure and heart rate. ${ }^{21}$ The amount of soursop leaves which is predicted it can decrease the blood pressure is Potassium. ${ }^{22}$ Potassium Ion in extracell liquid will effect the heart to be relax and makes the fruquency of heart beat to be slow. Potassium also manages the balance of the body liquid with natrium, then it obstructs renin outcome, it has the role in arteriol 
vasodilatation and detracts the responce of endogen vasocontryction, so the blood pressure will be dropped down. ${ }^{23}$ Research conducted by Tanjung gets the result that consuming skin mangosteen juice significantly can decrease the blood pressure on hypertension victims. ${ }^{24}$ This case is appropriate with the research conducted by Jung et.al which shows that there are five anti-oxida in mangosteen skin such as $\alpha$-mangostin, $\beta$-mengaostin, $\gamma$ mengostin, mangostinone, garcinon $\mathrm{E}$ which can obstruct the forming of lump blood so the stroke risk is minimized. ${ }^{25}$ The other result shows that some xanthan derivative compounds is proved antihypertensively then it has the effect to decrease the blood pressure in artery. ${ }^{26}$

\section{Conclusion}

Progressive Muscle Relaxation and SIRMA Dyeing Tea therapy has the significant influence toward the hypertension level on eldery, so this therapy can be recommended as one of the hypertension complementary therapies. Recommendation conducts the research with RCT design.

\section{References}

[1] Word Health Organization (WHO). Global Status Report On Noncommunicable Disease 2010. ISBN: 9789241564229.

[2] Riset Kesehatan Dasar. Jakarta: Badan Penelitian dan Pengembangan Kesehatan.Departemen KesehatanRepublik Indonesia, 2007.

[3] Triyanto. E. Pelayanan Keperawatan Bagi Penderita Hipertensi Secara Terpadu. Yogyakarta: Graha Ilmu, 2014.

[4] Potter, P.A. \& Perry, A.G. Buku Ajar Fundamental Keperawatan: Konsep, Proses, dan Praktik. Edisi 4.Volume 1. Alih Bahasa : Renata Komalasari,dkk. Jakarta: EGC, 2005.

[5] LeMone, P, Burke, Karen. Medical Surgical Nursing, Critical Thinking in Client Care (4th Edition). New Jersey: Prentice Hall Health, 2008.

[6] Lusia, Oktora, Ruma, Kumala, Sari. Pemanfaatan Obat Tradisional dengan Pertimbangan Manfaat dan Keamanannya. Sumber jurnal.farmasi.ui.ac.id, 2006.

[7] Kozier. Erb, Berman. Snyder. (2010). Buku Ajar Fundamental Keperawatan: Konsep, Proses \& Praktik, Volume : 1 , Edisi : 7. Jakarta: EGC, 2010.

[8] Lestari, P.K., Yuswiyanti, A. Pengaruh Pemberian Terapi Relaksasi Otot Progresif Terhadap Tingkat Kecemasan pada Pasien Pre Operasi di Ruang Wijaya Kusuma RSUD Dr. R Soeprapto Cepu. Jurnal Keperawatan Maternitas. Vol. 3. No. 1. Mei 2015.

[9] Murti, T. Perbedaan Tekanan Darah Pada Pasien Hipertensi Essensial Sebelum Dan Sesudah Pemberian Relaksasi Otot Progresif Di RSUD Tugurejo Semarang, 2011.

[10] Tyani, E., S., Utomo.,W. Hasneli.,Y. Efektifitas Relaksasi Otot Progresif Terhadap Tekanan Darah Pada Penderita Hipertensi Esensial, JOM Vo.2 No.2 Oktober 2015 hal 10681075

[11] Chen, Y.I. Normalization Effect of Sport Training on Blood Pressure in Hypertensives. Journal of Sport Sciences 2010. $28,361-367$.

[12] Sulistiyarini, I. Terapi Relaksasi untuk Menurunkan Tekanan Darah dan Meningkatkan Kualitas Hidup Penderita Hipertensi, Jurnal Psikologi. Volume 40. No 1. Juni 2013 28-38.

[13] Valvogli,L. \& Darviri,C. Stress Management Tehniques, Evidence Based Prosedures That Reduce Stress And Promote Health. Health Science Journal 2011, 5(2), 74-89.

[14] Shinde N, et.all. Immediate Effect of Jacobson's Progressive Muscular Relaxation in Hyperpressure. Scholars Journal of Applied Medical Sciences (SJAMS). ISSN 2320-6691. Sch. J. App. Med. Sci., 2013; 1(2):80-85.

[15] Amila. Pengaruh Progresive Muscle Relaxation terhadap Penurunan tekanan Darah dan Kecemasan pada Pasien Stroke di ruang Neurologi RSCM Jakarta. Jurnal Kesehatan 2014. Vol. 4. No. 1.

[16] Maghfirah, S., Sudiana, K., Widyawati, Y.K. Relaksasi Otot Progresif Terhadap Stres Psikologis dan Perilaku Perawatan Diri Pasien Diabetes Mellitus Tipe 2. Jurnal Kesehatan Masyarakat 2015.Vol. 10. No. 2.

[17] Kumutha, Aruna, Poongodi. Effectiveness of Progressive Muscle Relaxation Technique on Stress and Blood Pressure among Elderly with Hyperpressure. IOSR Journal of Nursing and Health Science (IOSR-JNHS) e-ISSN: 2320-1959.p- ISSN: 2320-1940 Volume 3, Issue 4 Ver. II (Jul-Aug. 2014), PP 01-06.

[18] Syaifudin, Muh. Penggunaan Tanaman Herbal Pada Lansia Penderita Hipertensi Di Kecamatan Gatak Kabupaten Sukoharjo. Universitas Muhammadiyah Surakarta, 2013.

[19] Pugar, Hubert Hansel. Pengaruh Teh Daun Sirsak (Annona Muricata Linn) Terhadap Penurunan Tekanan Darah Normal Pada LakiLaki Dewasa Muda. Universitas Kristen Maranatha, 2013.

[20] Sriyono dan Jujul P. Pengaruh Pemberian Teh Hijau Terhadap Tekanan Darah dan Kadar Kolesterol (LDL) pada Lansia dengan Hipertensi. The Soedirman Jurnal Of Nursing 2012. Vol.7 No 1..

[21] Nwokocha et.al. Possible Mechanisms Of Action Of The Hypotensive Effect Of Annona Muricata (Soursop) In Normotensive Sprague-Dawley Rats. Pharmaceutical Biology. 2012 Nov;50(11):1436-41. doi: 10.3109/13880209.2012.684690.

[22] Nafrialdi. Farmakologi dan Terapi. Edisi 5. Jakarta: Departemen Farmakologi dan Terapeutik, Fakultas Kedokteran universitas Indonesia. P.341-346, 2007.

[23] Hasnawati, Eka. Keajaiban Sirsat Menumpas 7 Penyakit. Yogyakarta: Easymedia, 2012.

[24] Jung, H. A.. et.al. Antioxidant Xanthones from The Pericarp of Garcinia mangostana (Mangosteen). J Agric. Food. Chem, 54, 20772082, 2006

[25] Tanjung, S F. Pengaruh Jus Kulit Manggis dan Madu Terhadap Tekanan Darah Penderita Hipertensi di Dusun Gamping Lor Sleman Yogyakarta. Naskah Publikasi STIKES Aisyiyah Yogyakarta, 2014.

[26] Hasanah. Khasiat Istimewa Manggis.Jakarta : Dunia Sehat, 2013. 